\title{
Status and distribution of the Pemba flying fox Pteropus voeltzkowi
}

\author{
Abigail Entwistle and Nadia Corp
}

The Pemba flying fox Pteropus voeltzkowi is a fruit bat endemic to the island of Pemba, off Tanzania. A total of 41 reported roosting areas were visited in June and July 1995, and 19 occupied roosts were located, most of them in the west of the island, and on small islets off the west and south of Pemba. Roosts were situated in primary forest, secondary forest (overgrown clove plantations), traditional graveyards and mangrove areas. A range of sizes and species of trees were used as roosts. The minimum population of $\mathrm{P}$. voeltzkowi was estimated to be between 4600 and 5500 individuals. In total 94 per cent of the population was located at 10 roost sites. Larger colonies were associated with roosts located in forests, which together supported 75 per cent of the total bat population. Colonies were of mixed sex, but no young or obviously pregnant females were observed. Major threats to this species appeared to be hunting and deforestation (both logging and clearing for agriculture) and $\mathrm{P}$. voeltzkowi is considered to be endangered.

\section{Introduction}

Nine species or subspecies of Pteropus occur in the western Indian Ocean, of which six are considered to be at least threatened (Mickleburgh et al., 1992). Common threats affecting bats of the genus Pteropus include hunting, deforestation and destruction as pests (Racey 1979; Mickleburgh et al., 1992; Pierson and Rainey, 1992; Reason and Trewhella 1994). The Pemba flying fox Pteropus voeltzkowi is endemic to the island of Pemba and is listed as endangered in the 1994 IUCN Red List of Threatened Animals (Groombridge, 1993) and in the IUCN fruit bat action plan (classed as priority 1; Mickleburgh et al., 1992).

Pemba Island lies in the western Indian Ocean, $40 \mathrm{~km}$ off the coast of mainland Tanzania (Figure 1), and a similar distance from the island of Zanzibar (Unguja). Pemba is approximately $68 \mathrm{~km}$ long and $23 \mathrm{~km}$ wide, with numerous smaller islets off the coast. Although originally forested, most of the primary forest on the island has now been lost. The vegetation on Pemba is dominated by plantations of cloves and other spices, although two major remnants of primary forest are protected as forest reserves. Much of the area covered by clove plantations has been abandoned and is now dominated by secondary growth forest. The island varies topographically between the east and west. The west of the island contains a series of ridges, which are separated by steep valleys and are often forested (Pakenham, 1984). In contrast, the east of the island is much flatter and more arid. The climate shows seasonal variation, with extensive rains in April and May, and a shorter rainy season between October and November.

Twenty seven mammalian species have been reported from Pemba, including 13 bat species (Pakenham, 1984), but $P$. voeltzkowi is the only endemic mammalian species on the island. Of the four species of Megachiroptera found on Pemba (also including Eidolon helvum, Epomophorus wahlbergi and Rousettus aegypticaus; Pakenham, 1984), $P$. voeltzkowi is distinctive because of its larger size and chestnut-red coloration. However, many villagers are unaware that there is more than one type 
of bat on the island (Entwistle and Corp, 1995), which may be a potential source of confusion in assessing the status of this species.

Andersen (1912) suggested that $P$. voeltzkowi only occurred at a single site on Pemba. However, several roosts were subsequently located in 1945 (Pakenham, 1984). More recent studies in 1989 suggested a dramatic population decline, with fewer than 10 individuals being seen, and the species was considered to be on the brink of extinction (Seehausen, 1991a). However, in 1992, surveys indicated a population in the region of $2400-3600$, although it was estimated that the population may have declined significantly in the preceding decade (Seehausen et al., 1994). As a result of these studies a captive-breeding programme was initiated in 1994, based at Phoenix Zoo, Arizona, USA. However, no monitoring of the wild population had been carried out since 1992. This project therefore aimed to assess the population and to collect information about the ecology of the species (including roosting habitat) and threats to its survival, in order that appropriate conservation policies might be developed.

\section{Methods}

\section{Roost survey}

Reports of roosts were collected from local villagers, schoolchildren and previous records. Within each general roost area villagers were asked to identify specific roosting sites in the vicinity. Roosts were then checked within as short a time as possible to minimize the chances of bats shifting between successive roost sites and thus being counted more than once. Adjacent roost sites were visited within the same day for the same reason. The roost survey was carried out intensively between 6 and 20 June 1995, with an additional five roosting areas checked on dates up to 3 July 1995.

\section{Roost features}

Roost location and characteristics were recorded from verified roosts (i.e. where bats were present). A grid reference for the location of the roost was taken, and the distance to the nearest village and to worked fields was estimated. The general habitat type in which the roost site was located was recorded. In addition, the position of the roost in relation to topographical features, including ridge tops, was noted. Potential sources of disturbance at each roost were assessed from information collected from guides and from direct observation. Sources of disturbance included logging, agricultural work and hunting of the bats.

The data collected from roost trees included species, diameter at breast height (d.b.h.), height of the tree (estimated), and foliage cover (from both standard photographs taken directly underneath the canopy, and by whole tree estimates).

\section{Population assessment}

Binoculars were used to make complete counts of all individuals visible at each roost. However, at roosts where observation was restricted, patch counts (Thomas and LaVal, 1988) were employed. In addition, where bats were bunched tightly, an estimate of the possible number of bats hidden from view was made.

\section{Identification of threats to Pteropus voeltzkowi}

Because direct observation of most threats to the bats was not possible, we collected anecdotal information from villagers and guides. Questions were asked using an informal, opportunistic approach, to determine possible threats, sources of disturbance and any conflicts with local villagers. Any inconsistencies in the responses were addressed. Additional sources of evidence, such as signs of logging, were also noted.

\section{Results}

Roost survey

A total of 41 reported roost areas were visited, and, from these, 19 occupied roost sites were 
Figure 1. Map of the western Indian Ocean showing the position of Pemba.

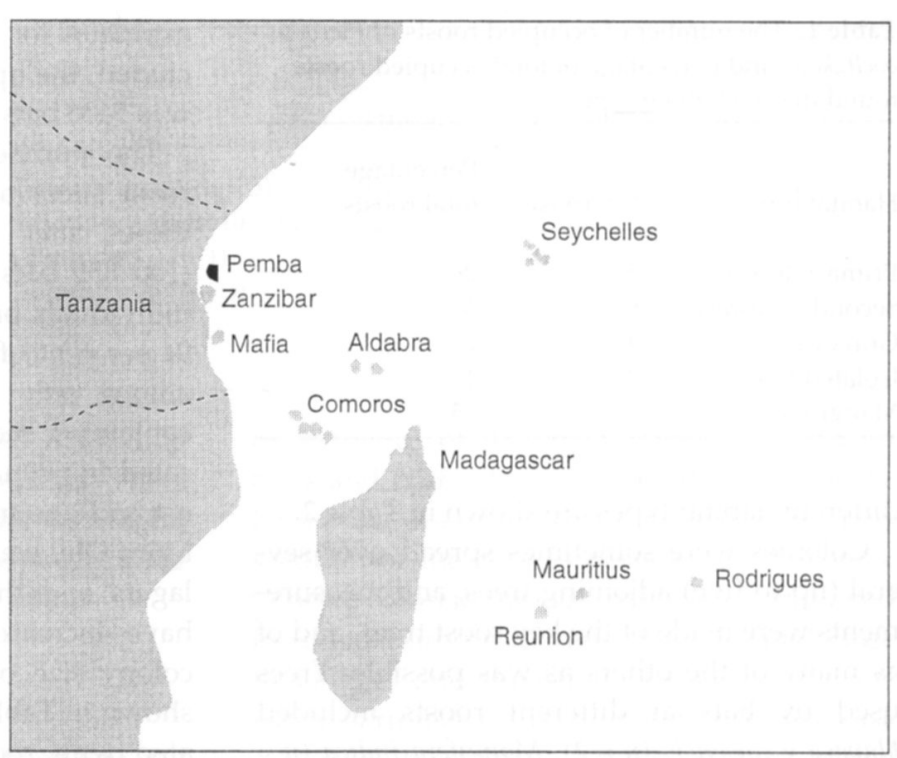

located (Figure 2). Roosts were located both on the main island and on some of the smaller islands. More roosts were located in the west ( $n=12$ ) compared with the east $(n=7)$ of the island, but the difference was not significant (binomial comparison, $P>0.05$ ). Within roosting areas, between one and four specic roosting sites were reported. However, at any one time only one roost site in any roost area was ever occupied by bats.

\section{Characteristics of roosts}

Occupied roosts were located in primary forest (including the Ngezi forest reserve), secondary forest (generally overgrown clove plantations), traditional graveyards (protected from logging by religious taboo), mangroves and occasionally in isolated trees (Table 1). Of the six ( 33 per cent) roosts located in hilly areas, all were situated on ridge tops. The other 13 roosts were located in areas that were more or less flat. Eighteen roosts were between $100 \mathrm{~m}$ and $5 \mathrm{~km}$ from villages, although one was located in the centre of a village. Roosts in forests were further from villages (mean $2.2 \mathrm{~km}, \mathrm{SD}=1.46, n=11$ ), than those in graveyards or in isolated trees (mean $=0.96$ $\mathrm{km}, \mathrm{SD}=0.90, n=7$; $t$-test, $t=2.98, P<0.05)$. Sources of disturbance reported at roosts in

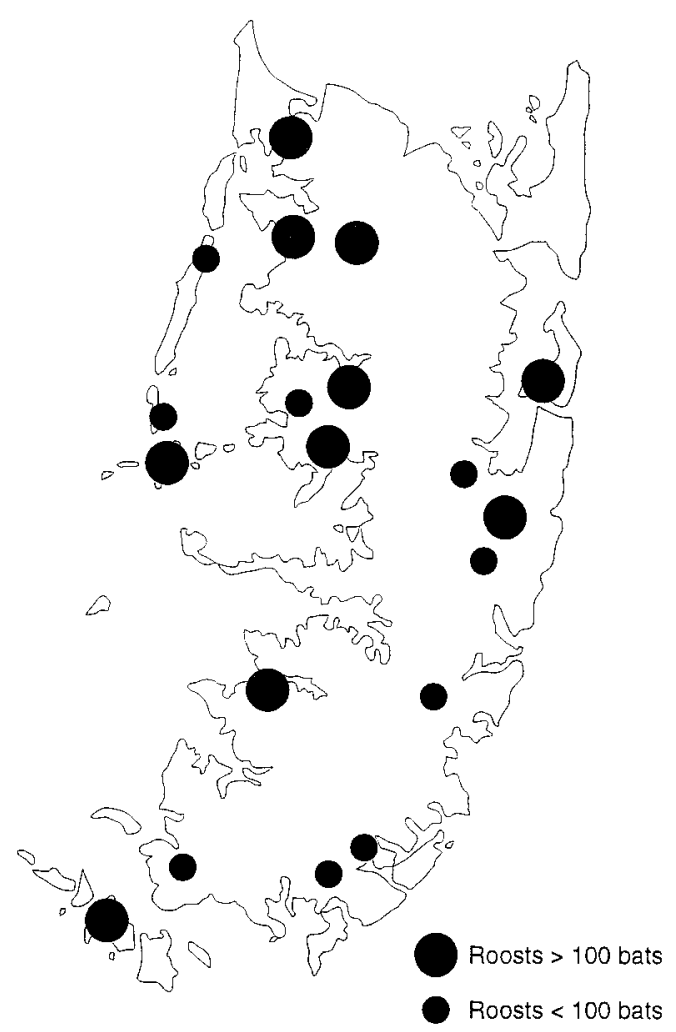

Figure 2. The location of occupied roosts of Pteropus voeltzkowi on Pemba. 
Table 1. The number of occupied roosts of Pteropus voeltzkowi and percentage of total occupied roosts found in each habitat type

\begin{tabular}{lll}
\hline Habitat type & No. roosts & $\begin{array}{c}\text { Percentage } \\
\text { total roosts }\end{array}$ \\
\hline Primary forest & 5 & 26 \\
Secondary forest & 6 & 32 \\
Graveyard & 4 & 21 \\
Isolated tree & 3 & 16 \\
Mangrove & 1 & 5 \\
\hline
\end{tabular}

different habitat types are shown in Table 2.

Colonies were sometimes spread over several (up to five) adjoining trees, and measurements were made of the key roost trees, and of as many of the others as was possible. Trees used by bats at different roosts included Uapaca guineensis $(n=2)$, Mangifera indica $(n=$ $2)$, Ficus natalensis $(n=2)$, Ficus lutea $(n=1)$, Syzygium jambolanum $(n=2)$, Terminalia catappa $(n=2)$, Adansonia digitata $(n=2)$, Antiaris toxicaria $(n=1)$, Erythrophleum suaveolens ( $n=$ 6), Afzelia quanzensis $(n=1)$, Parinari curatellifolia $(n=3)$ and Blighia unijugata $(n=1)$. Where bats used several trees of the same species at a single roost site, measurements were taken from a single representative tree to avoid pseudo-replication. Estimated heights of roost trees ranged from 15 to $25 \mathrm{~m}$ (mean $=18.6 \mathrm{~m}$, $\mathrm{SD}=3.55 \mathrm{~m}, n=21$ ), and diameters (as d.b.h.) of trees ranged between 0.1 and $1.9 \mathrm{~m}$ (mean = $0.54 \mathrm{~m}, \mathrm{SD}=0.47 \mathrm{~m}, n=22$ ). All roost trees were relatively highly foliated, and estimates of cover ranged from 40 to 100 per cent (median $=70$ per cent).

\section{Population estimate}

Direct counts were made at all but three roosts, where bats were obscured by foliage and for these latter roosts patch counts were made instead. At six roosts bats were roosting densely within foliage, and an estimate was made of animals that may have been hidden from view (estimates between 20 and 50 per cent of visible colony, at different sites). At one site an average of counts made on two occasions was used. The total number of bats counted in all colonies was 4608. When estimates for bats hidden from view were included, the upper estimate for population size was 5458 bats.

The number of bats counted at different roost sites ranged from one to 855 . Ten of these sites contained sizeable colonies (100-855 bats), while nine contained solitary individuals or small colonies $(<100)$. Indeed, 94 per cent of the population was distributed among only 10 colonies. Of the 10 colonies containing more than 100 bats, four were located in primary forest, five in secondary forest and one in a graveyard. This last roost, at Mjini Ole, was actively protected by local villagers and the number of bats appeared to have increased over recent years. Average colony size of roosts in different habitats is shown in Table 3. Larger colonies were associated with roosts in primary and secondary forests compared with those in graveyards, excluding the one actively protected graveyard roost ( $t$-test, $t=4.47, n=17, P<0.005$ ).

Observations of roosting bats revealed that both males and females were present within colonies, but no assessment of overall sex ratio could be made. Of the bats identified, it was noted that males appeared to be larger with a darker red pigmentation. Observations of the colonies revealed no young bats or obviously pregnant females at any roost site.

\section{Threats to bats}

\section{Hunting}

Hunting in some form was reported at 13 of the 19 occupied roost sites. In addition, at five roosts at which bats were not found there appeared to have been recent hunting. The extent of hunting may vary seasonally because bats were considered a particularly important dietary component during June and July.

Traditional hunting methods include the use of thorny bushes on sticks to ensnare bats during the day or at feeding trees during the night. In addition, catapults or sticks are used to knock bats out of roost trees in daytime. Modern hunting methods include the use of shotguns. Such hunting takes place at roost trees during daytime. Shotgun hunting was 
Table 2. Number of Pteropus voeltzkowi roosts in each habitat type that are prone to three nonexclusive sources of disturbance

\begin{tabular}{llll}
\hline & Hunting & Logging & $\begin{array}{l}\text { Agriculture/ } \\
\text { noise }\end{array}$ \\
\hline Primary forest $(n=5)$ & 2 & 2 & 1 \\
Secondary forest $(n=6)$ & 5 & 2 & 1 \\
Graveyard $(n=4)$ & 3 & 0 & 4 \\
Isolated tree $(n=3)$ & 2 & 0 & 3 \\
Mangrove $(n=1)$ & 1 & 0 & 0 \\
Overall $(n=19)$ & 13 & 4 & 9 \\
\hline
\end{tabular}

reported at nine occupied roosts, including four of the major roost sites identified. There was no evidence that the bats shot were sold, but were distributed between members of the hunting party for private consumption.

\section{Habitat destruction}

Six roosts were reported to have been lost as a result of both logging (for timber and firewood) and from the clearing of forests for agriculture. The larger, mature trees used as roosts by $P$. voeltzkowi are those most likely to be selected for timber, and several of the tree species used as roosts (including Mangifera, Erythrophleum, Afzelia and Syzigium) are important sources of timber for building. The poor soils and lowered productivity in many parts of the island following deforestation are resulting in a pattern of shifting agriculture as local farmers reclaim areas of woodland and subsequently move on.

\section{Other threats}

Villagers considered that bats damaged fruit, particularly mangoes, and this was supported by evidence of damaged mangoes found on trees and half-eaten fruit found under roosts. However, there was no evidence of persecution of the bats as pests by the villagers. Other potential threats that were mentioned included burning of roost trees located close to villages and ingestion of poisonous fruits (such as rubber fruits) by the bats. In one case a bat was reported to have been electrocuted when feeding close to electricity wires. Given the development of electrification on Pemba and its effects on fruit bats elsewhere (Cheke and Dahl, 1981), this may be a growing threat for this species.

\section{Discussion}

\section{Roosting habitat}

Forests appear to provide key roosting habitat for $P$. voeltzkowi. Most roosts were in forests and these sites supported larger colonies containing 75 per cent of the population. Forests may provide cover and protection for the bats, and the availability of suitable roost trees is probably higher in forest. In addition, roosts in forests appeared less prone to

Table 3. The mean and range of Pteropus voeltzkowi colony size, along with the total number of bats and percentage of the population found at roosts in different habitat types. A second estimate for roosts in graveyards is presented, which excludes one roost which was actively protected

\begin{tabular}{lcccc}
\hline Habitat type & Mean colony size & Range & Total no. bats & \% of total population \\
\hline Primary forest & $339(\mathrm{SD}=219)$ & $2-583$ & 1695 & 37 \\
Secondary forest & $305(\mathrm{SD}=213)$ & $50-627$ & 1829 & 40 \\
Graveyard & $247(\mathrm{SD}=406)$ & $1-855$ & 988 & 21 \\
$\quad$ (excluding Ole roost) & $44(\mathrm{SD}=38)$ & $1-70$ & $(133)$ & $(3)$ \\
Isolated tree & $30(\mathrm{SD}=32)$ & $1-65$ & 91 & 2 \\
Mangrove & $5(\mathrm{SD}=249)$ & - & 5 & - \\
Overall & $243(-855$ & 4608 & 100 \\
\hline
\end{tabular}


disturbance. The westerly distribution of roost sites may also be explained by the distribution of forests on the island, although no bats were found in Msitu Mkuu, a large fragment of primary forest in the east of the island. In the west of the island the bats may benefit from roosting near the top of ridges, the inaccessibility of which may protect them from human interference and may also provide opportunities for free- fall take off. A number of roosts were located on smaller islands, off the west, east and south of Pemba. Many of the smaller islands contained areas of relatively undisturbed natural forest and had lower population densities than the main island. In addition, hunting appeared infrequent on all but one of the smaller islands. Coastal islands may therefore currently be an important refuge for the bats. However, increasing settlement of these areas may affect the bats' abilities to survive. In other areas, traditional graveyards, where logging is prohibited, may provide pockets of suitable, undisturbed roosting habitat in otherwise impoverished agricultural areas. Graveyards, especially when they are actively protected as at Mjini Ole, may therefore be important refugia for $P$. voeltzkowi.

According to villagers and to references in the literature dating back as far as 1945 (Kingdon, 1974; Pakenham, 1984; Bentjee, 1990), many of the roosts identified in the present study had supported bat colonies in previous years. This indicates that many of the roost sites are traditional and have been used over a long period of time, although occupation at some of these sites may have been on a seasonal basis. Long-term roost fidelity may make these bats a predictable target for hunters, and may also increase the impact of roost destruction on colonies. Most of the population (94 per cent) was located in only 10 sites and these may be of key importance in the protection of this species.

\section{Roost characteristics}

There was little indication of a distinct preference for one type or size of tree, although Erythrophleum suaveolens was used more than other species (23 per cent of records). Most roosts were highly foliated, in contrast to the bare branches of roost trees used by many other species of Pteropus (Pierson and Rainey, 1992). Pteropus voeltzkowi may benefit from foliage cover as a protection from insolation (Advani, 1982) and from predators, particularly given this species's conspicuous coloration. Because of time constraints and the danger of disturbing the bats, it was not possible to collect data from the other trees available in the vicinity of roosts, which would have revealed to what extent the bats are selective of particular types of trees as roosts.

\section{Status of the population}

Although the number of bats recorded in the present study (4608-5450) is higher than the 1992 estimate of $2400-3600$ individuals (Seehausen et al., 1994), differences in the distribution of the bats during the two studies mean that our estimates are not directly comparable and there do not appear to have been any dramatic changes in the population over the last 3 years.

There may be various sources of error, which would affect the accuracy of the quoted estimates.

1 The same bats may have been counted at different sites. Without marking animals individually it was not possible to demonstrate conclusively that the colonies surveyed were independent, and thus could be summed to an overall population estimate. However, by surveying as many roosts as possible within a limited time and colonies close to each other on the same day, it was anticipated that errors linked to the movement of bats between roosts, and consequent overestimation, would be minimized. However, it is possible that the smaller colonies observed (i.e. $<100$ individuals) were satellite colonies of the main roosts. In total 278 individuals were counted in these smaller colonies.

2 Important roost sites may have been missed. It seems unlikely that a major roosting site would be missed given the extent of local knowledge about the whereabouts of the bats. However, it is possible that colonies that were 
reported but could not be located, had moved into inaccessible areas. If colony size estimates made by villagers (likely to be overestimates) were accepted for these roosts this would account for a further 1000 individuals in total.

3 Patch counts. The accuracy of patch counts (in which the number of bats in a patch of a given size is used to estimate the number of bats in a whole tree) was not known, although generally this method does not appear to result in consistent over- or underestimation (Thomas and LaVal, 1988). Patch counts were used only at three roosts where the whole colony was not visible from our vantage point. It therefore seems unlikely that the use of patch counts would have affected the population estimate by more than \pm 500 individuals (half of the estimates made at these roosts).

Taking into account these potential sources of error, we suggest the population size could be as low as 3800 and as high as 7000 bats, but we estimate that the actual population is most likely to be between 4600 and 5500 individuals.

Mickleburgh et al. (1992) suggested that young of this species are born in June/July, but no evidence of this was found in the present study. Instead, villagers reported that bats with young were first seen in August and September ('the time of the rice harvest'). This is supported by reports of juveniles present at roosts in August (Kingdon, 1974) and in October (Seehausen, 1991b).

\section{Threats identified}

It is clear that shotgun hunting could potentially affect bat numbers and may result in disturbance to colonies. Although it is difficult to accept anecdotal evidence about the size of catches, reports indicated that as many as 40 bats (filling two large sacks) were caught on occasion, although most reported catches were in the range of five to 20 bats. The low reproductive rates of Pteropus species may result in slow recovery of colony numbers following hunting. The importance of bats as a source of protein to local villagers needs further assessment. However, it is clear that these villagers seldom have access to shotguns, which would

(C) $1997 \mathrm{FFI}$, Oryx 31 (2), 135-142 appear to inflict the heaviest damage on the bat numbers. Instead, local villagers appear to be more likely to hunt using traditional methods, which have presumably been used sustainably over many years, and do not appear to have had a highly significant impact on bat populations. Although the Islamic religion forbids the eating of bats (because they have claws and use their feet in the consumption of food), this did not seem to be recognized among villagers (Walsh, 1995). There was no evidence that bats were killed as pests by villagers, rather the potential benefits of bats as food may outweigh the damage caused, and other species (vervet monkeys and birds) were perceived to be more damaging to crops.

Deforestation results in the loss of roosting sites and the loss of potential food sources. Additionally, encroachment of agricultural land into the forests may make bats more easily located by hunters. The noise caused by logging and nearby agriculture may also disturb the bats, leading to a shift in roosting site. Because roosts are seldom situated close to villages and worked fields, the loss of forests is likely to lead to further restriction in the range of $P$. voeltzkowi. The use of traditional roost sites also means that logging of specific, relatively small patches of forest may result in the loss of whole colonies. It is evident that deforestation may prove a severe threat to $P$. voeltzkowi, in particular if secondary clove forest is further redeveloped for alternative crops. Given the current human population density (estimated at around 280 per sq $\mathrm{km}$ ) and projected population increase over the next 20 years, the threat of deforestation on Pemba can only increase. In the long term, habitat loss may be the greatest threat to the survival of $P$. voeltzkowi on Pemba.

\section{Conclusions}

The population of Pteropus voeltzkowi is higher than that reported in previous surveys but there is little evidence of a real increase in the numbers of bats, and the difference can be explained by anomalies in sampling techniques. 
It seems most likely that the population has not changed substantially over the last 3 years. The low population numbers (fewer than 6000 mature individuals) and restricted range (extent of occurrence is $1014 \mathrm{sq} \mathrm{km}$ and area of occupancy is much less) mean that this species should be considered endangered under the new IUCN criteria (IUCN/SSC, 1994). The possibility of rapid population decline in this species exists, given the threats from hunting and deforestation. Most of the population is distributed in only a few sites, which puts it at particular risk. Further assessments are required to monitor the status of the population in future years.

\section{Acknowledgements}

This project was carried out in collaboration with the Sub-Commission of Forestry and Department of Environment on Zanzibar and Pemba. We would like to thank Mr Salim Rashid Abdallah of the Department of the Environment and the head of the Sub-Commission of Forestry, who both provided help and logistical support. Masoud Abdallah Hemed and Khamis A. Said provided invaluable help and advice throughout the course of this project. We would also like to thank Hamza Zubier Rijaland P. J. Stephenson. Ole Seehausen, Reg Hoyt and Roland Wirth all provided invaluable help in planning this project. Paul Racey and Simon Mickleburgh provided advice and commented on the manuscript. The project was funded by Fauna \& Flora International, People's Trust for Endangered Species, the Carnegie Trust for the Universities of Scotland, British Airways Assisting Nature Conservation and the Percy Sladen Memorial Fund.

\section{References}

Advani, R. 1982. Distribution and status of Chiroptera species in Rajasthan, India. Saugettier Kundliche Mitt. 30 (1), 49-52

Andersen. K. 1912. Catalogue of the Chiroptera in the Collections of the British Museum. I. Megachiroptera, 2nd edn. British Museum (Natural History), London.

Bentjee, H.J. 1990. Botanical Assessment of the Ngezi Forest, Pemba. Forestry Development Project, Technical Paper 1. Forestry Department Zanzibar/FINNIDA.

Cheke, A.S. and Dahl, J.F. 1981. The status of bats on western Indian Ocean islands, with special reference to Pteropus. Mammalia, 45, 205-237.

Entwistle, A. C. and Corp, N. 1995. The Status and Conservation of the Pemba Flying Fox, Pteropus voeltzkowi. Unpubl. report, Aberdeen University, Aberdeen.

Groombridge, B. (ed.). 1993. 1994 IUCN Red List of Threatened Animals. IUCN, Gland, Switzerland and Cambridge, UK.

Kingdon, J. 1974. East African Mammals. An Atlas of Evolution in Africa. Vol. IIA. Insectivores and Bats. University of Chicago Press, Chicago.

Mickleburgh, S.P., Hutson, A.M. and Racey, P.A. 1992. Old World Fruit Bats. An Action Plan for their Conservation. IUCN, Gland, Switzerland and Cambridge, UK.

Pakenham, R.H.W. 1984. The Mammals of Zanzibar and Pemba Islands. Privately published by the author.

Pierson, E.D. and Rainey, W.E. 1992. The biology of flying foxes of the genus Pteropus: a review. In Pacific Island Flying Foxes: Proceedings of an International Conservation Conference (eds D. E. Wilson and G. L. Graham). US Fish and Wildlife Service Biological Report 90 (23).

Racey, P.A. 1979. Two bats in the Seychelles. Oryx, 15, $148-152$

Reason, P.F. and Trewhella, W.J. 1994. The status of Pteropus livingstonii in the Comores. Oryx, 28, 107-114.

Seehausen, O. 1991a. The Pemba fruit bat - on the edge of extinction? Oryx, 25, 110-112.

Seehausen, O. 1991b. The endemic Pemba flying fox. Miombo, 6, 12-13.

Seehausen, O., Ali, S.J., Juma, K.M., Mbarouk, A.A., Mchenga, A.S., Mohammed, M.A. and Mohammed, Z. 1994. Zwischenbericht zum Projekt Pembaflughund. Newsletter of the Zoological Society for the Conservation of Species and Populations, 9 (2), 14-15.

Thomas, D.W. and LaVal, R.K. 1988. Survey and census methods. In Ecological and Behavioural Methods for the Study of Bats (ed. T. H. Kunz). Smithsonian Press, Washington DC.

Walsh, M. 1995. Eating bats on Pemba Island: a local innovation or cultural borrowing? Muita, Oct 1995, 15-18.

Abigail Entwistle* and Nadia Corp, Zoology Department, Aberdeen University, Aberdeen AB24 2TZ, UK.

*Address for correspondence: Abigail Entwistle, Fauna \& Flora International, Great Eastern House, Tenison Road, Cambridge CB1 2DT, UK. 